\title{
Design and synthesis of novel bis-annulated caged polycycles via ring-closing metathesis: pushpakenediol
}

\author{
Sambasivarao Kotha* and Mirtunjay Kumar Dipak
}

\author{
Full Research Paper \\ Address: \\ Department of Chemistry, Indian Institute of Technology-Bombay, \\ Powai, India, Fax: 022-2572 7152 \\ Email: \\ Sambasivarao Kotha* - srk@chem.iitb.ac.in \\ * Corresponding author \\ Keywords: \\ Diels-Alder cycloaddition; Grignard addition; pentacycloundecane \\ (PCUD); ring-closing metathesis
}

\author{
Beilstein J. Org. Chem. 2014, 10, 2664-2670. \\ doi: $10.3762 /$ bjoc. 10.280 \\ Received: 11 August 2014 \\ Accepted: 31 October 2014 \\ Published: 13 November 2014 \\ Associate Editor: I. Marek \\ (c) 2014 Kotha and Dipak; licensee Beilstein-Institut. \\ License and terms: see end of document.
}

\begin{abstract}
Intricate caged molecular frameworks are assembled by an atom economical process via a Diels-Alder (DA) reaction, a Claisen rearrangement, a ring-closing metathesis (RCM) and an alkenyl Grignard addition. The introduction of olefinic moieties in the pentacycloundecane (PCUD) framework at appropriate positions followed by RCM led to the formation of novel heptacyclic cage systems.
\end{abstract}

\section{Introduction}

Caged polycyclic compounds draw the attention of synthetic organic chemists due to their unusual reactivity patterns as well as their strained nature [1-9]. Several pentacycloundecane (PCUD) related molecules were found to be key structural elements in various drugs [10-12], high-energy materials [13$15]$ and supramolecules $[16,17]$.

In addition, caged molecules possess unusual and often unique properties that are associated with their rigid carbocyclic framework $[1,2]$. They are useful synthons in the design and synthesis of natural as well as non-natural products $[3,4]$. Several intricate targets (Figure 1), such as snoutane (1) [18], basketane (2) [19], tetrahedrane (3) [20], triprismane [21], rocketene (4) [22], cubane (5) [23], garudane (6) [24], dodecahedrane (7)
[25,26] and golcondane (8) [27] were assembled by employing various novel synthetic routes.

\section{Results and Discussion}

In connection with our interest to prepare annulated PCUD, we proposed various dialkylated pentacyclic diones such as 1,9dialkylpentacyclo[5.4.0.0 $\left.0^{2,6} \cdot 0^{3,10} \cdot 0^{5,9}\right]$ undeca- 8,11 -dione 12 by using [4+2] and [2+2] cycloaddition strategies, which involve the DA reaction of 2,5-dialkyl-1,4-benzoquinone $\mathbf{1 0}$ and 1,3cyclopentadiene (9) followed by the formation of the cyclobutane ring through a $[2+2]$ photocycloaddition reaction (Figure 2). Later on, one can introduce two allyl groups by using traditional carbonyl chemistry. The addition of alkyl groups can take place from the less hindered exo side of this 


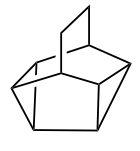
snoutane 1

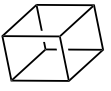

cubane

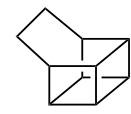

basketane

2

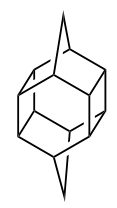

garudane
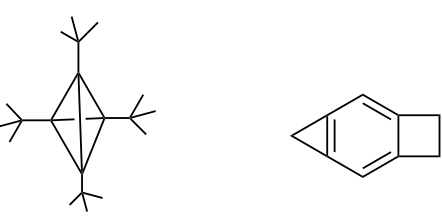

tetra-tert-butyltetrahedrane rocketene

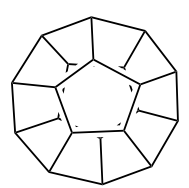

dodecahedrane

7

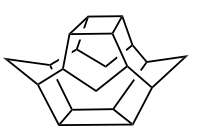

golcondane

8

Figure 1: Selected theoretically interesting molecules.

caged system. If the $\mathrm{R}$ and $\mathrm{R}$ ' groups contain unsaturated systems one can think of constructing additional rings on the pentacyclic framework by utilizing ring-closing metathesis (RCM). By varying the length of unsaturated component one can generate diverse PCUD ring systems.

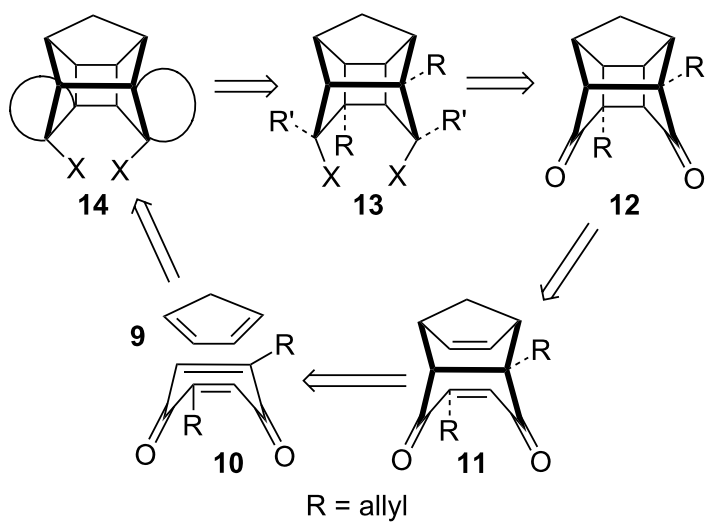

Figure 2: Retrosynthetic approach toward bis-annulated PCUD.

To realize the strategy depicted in Figure 2, we chose 2,5diallyl-1,4-benzoquinone (18) as a viable option. We deliberately choose two unsaturated $\mathrm{R}$ groups at non-vicinal positions, because we have shown in an earlier report that the vicinal allyl groups in PCUD can be converted to a six-membered ring by RCM [28]. Since the two allyl groups in the PCUD framework are far apart, they did not undergo a RCM reaction. Later, by introducing additional unsaturated fragments in the PCUD system one can generate multiple rings in the PCUD system by using the RCM protocol. To this end, we began with the Claisen rearrangement of bis(allyloxy)benzene $\mathbf{1 5}$ to deliver the two possible rearranged diallylated products 16 and 17 [29,30] in equimolar ratio. When 2,5-diallyl-1,4-hydroquinone (17) was subjected to $\mathrm{MnO}_{2}$ oxidation in acetone at room temperature the corresponding 2,5-diallyl-1,4-benzoquinone (18) was obtained in good yield (67\%). Since the quinone 18 is prone to polymerization (it gave a long streak on TLC when exposed to air at rt), it was immediately subjected to the $[4+2]$ cycloaddition reaction with freshly prepared 1,3 -cyclopentadiene (9) at $0-5{ }^{\circ} \mathrm{C}$ to deliver compound 19 in $71.5 \%$ yield (Scheme 1).

The formation of cycloadduct 19 was confirmed on the basis of ${ }^{1} \mathrm{H}$ and ${ }^{13} \mathrm{C}$ NMR spectral data. In ${ }^{1} \mathrm{H}$ NMR data the integration of the olefinic region (ring olefinic proton) corresponds to the three protons and, as the cycloadduct is unsymmetrical, all the seventeen carbons appeared in the ${ }^{13} \mathrm{C}$ NMR spectrum.

The stereochemistry of adduct $\mathbf{1 9}$ was expected to be endo as the reaction was performed at low temperature [28], and generally, the kinetically controlled product was produced under these reaction conditions. Our assumption was found to be correct, when we found that the DA adduct undergoes a smooth [2+2] photocyclization [31] upon exposure to UV light to generate caged dione $\mathbf{2 0}$ in good yield (80\%). The structure of the photoadduct was assigned as 1,9-diallyl PCUD 20 on the basis of the spectral data (Scheme 2).

Having prepared the pentacyclic diallyldione 20, we ventured into the synthesis of PCUD based novel heptacyclic systems. The dione $\mathbf{2 0}$ was subjected to an allyl Grignard addition reaction, which resulted in the formation of tetra-allyldiol 21. The structure of diol 21 was established on the basis of high field ${ }^{1} \mathrm{H}$ NMR (400 MHz) spectral data and further supported by ${ }^{13} \mathrm{C}$ NMR spectral data (Scheme 3). 

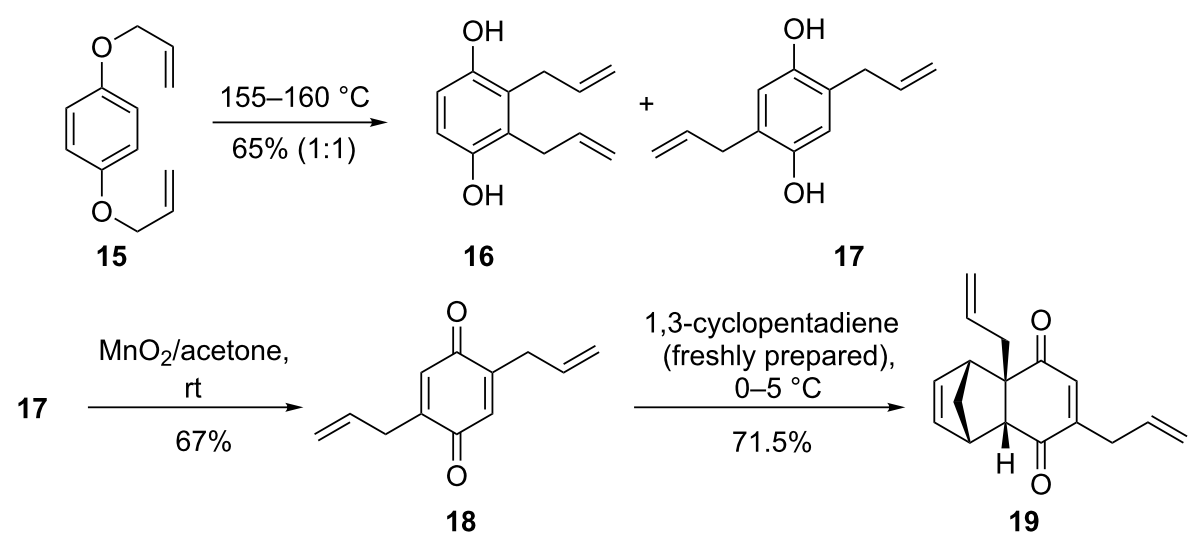

Scheme 1: The synthesis of diallylated tricyclic diene 19.

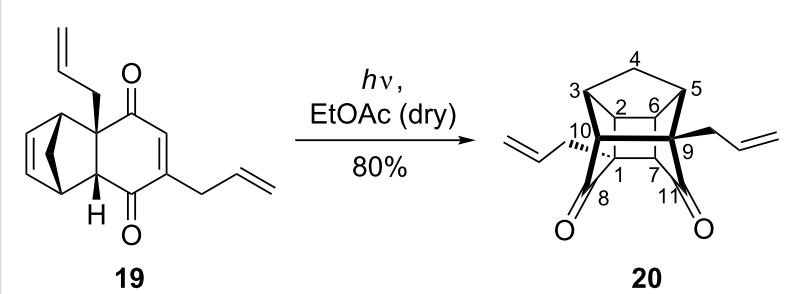

Scheme 2: The synthesis of diallylated pentacyclic dione 20.

The Grignard addition at a trigonal carbon may result in the formation of $\mathrm{C}-\mathrm{C}$ bond in two possible ways (en face and $z u$ face), but due to steric reasons only the exo-exo allyl addition product was isolated in the present case. The assumption of exo-exo stereochemistry has been further revived when the tetra-allyldiol 21 underwent a smooth RCM [32-37] upon its exposure to Grubbs' second generation catalyst to deliver bis-annulated heptacyclic diol 22 in good yield (72\%) (Scheme 3).

The molecular model and the optimized structure of heptacyclic diol 22 resembles the ancient flying machine "Puspak Viman" designed by the famous ancient aeronautical engineer saint Bhardwaj [38-40]. Therefore, we coined the name 'pushpakenediol' [41] for the heptacyclic diol. The optimization of the structure was carried out by means of Chem Draw 3D and

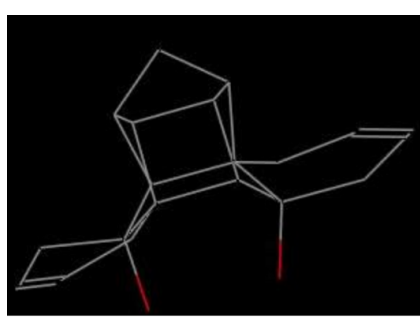

(a)

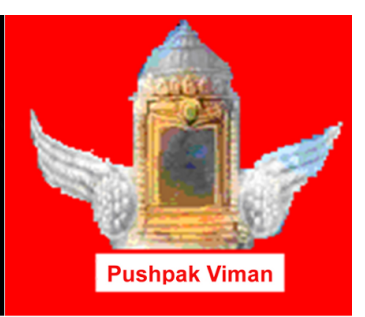

(b)
Figure 3: (a) Optimized structure of 22 (b) Ancient flying machine "Pushpak Viman".

the structure was visualized with the Mercury software (Figure 3).

We turned our attention toward the next target, i.e., the symmetrical heptacyclic diol $\mathbf{2 7}$, by adopting the ring-rearrangement metathesis (RRM) protocol [42]. To this end, hexacyclic diones 23 [28] and 25 [28] were treated with an excess amount of allylmagnesium bromide ( 6 equiv) at room temperature to give the desired diallylated adducts $\mathbf{2 4}$ and $\mathbf{2 6}$ as sole products in $82 \%$ and $85 \%$ yield, respectively (Scheme 4 ). The structures of the adducts $\mathbf{2 4}$ and $\mathbf{2 6}$ were established based on high field ${ }^{1} \mathrm{H}$ NMR (400 MHz) spectral data and further supported by ${ }^{13} \mathrm{C}$ NMR spectral data.

$$
20 \frac{\begin{array}{c}
\text { allylmagnesium bromide } \\
\text { ( } 6 \text { equiv), ether, } \mathrm{rt}
\end{array}}{70 \%}
$$

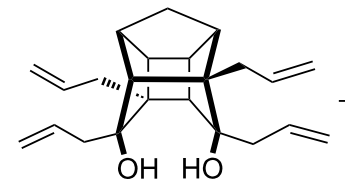

21

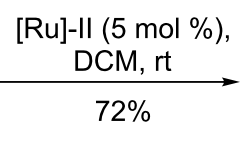
$\underset{72 \%}{\stackrel{\mathrm{DCM}, \mathrm{rt}}{\longrightarrow}}$

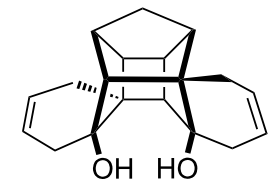

22 


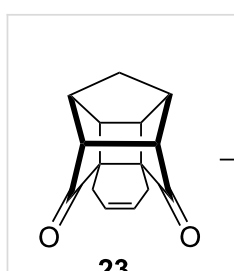

23

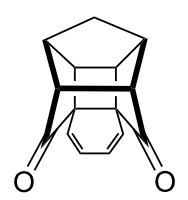

25

$$
\begin{aligned}
& \text { (6 equiv), } \\
& \text { ether, } \mathrm{rt}
\end{aligned}
$$

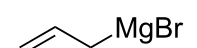

(6 equiv), ether, rt

$85 \%$

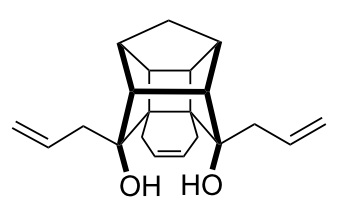

24

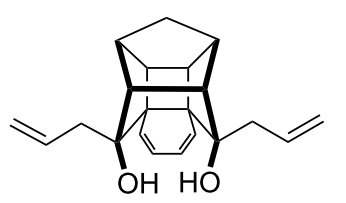

26

Scheme 4: The synthesis of diallylated hexacyclic diols.

It was anticipated that the two allyl groups and the cyclohexene moiety present in $\mathbf{2 4}$ would undergo a ring-rearrangement metathesis (RRM), [42] which involves the ring-opening and ring-closing metathesis sequence (ROM-RCM) in a single step to generate the novel heptacyclic system 27. However, even under harsh reaction conditions, we did not observe the formation of the required RRM product (Scheme 5).

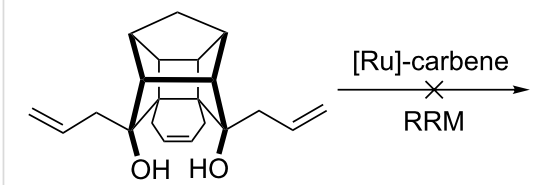

24

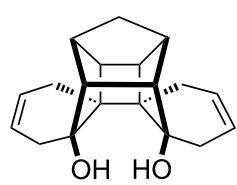

27

Scheme 5: The attempted synthesis of heptacyclic diol via ringrearrangement metathesis.

The RRM reaction was carried out under various reaction conditions with different metathesis catalysts, for example, with Grubbs' $1^{\text {st }}$ and $2^{\text {nd }}$ generation catalysts at $\mathrm{rt}$ as well as under reflux conditions. However, even the presence of ethylene during the metathesis sequence did not deliver the expected product, and the starting material remained unaltered (Scheme 5).

\section{Conclusion}

We demonstrated that the Grignard reaction in combination with the RCM reaction provides a useful strategy for the synthesis of novel and intricate molecular frameworks such as $\mathbf{2 2}$, which is suitable for studying stereoelectronic effects [43]. The strategy shown here is an atom economical process. The synthetic sequence opens up a new route to complex caged systems. At the same time non-participation of $\mathbf{2 4}$ in the RRM reaction reveals that systems which contain a sterically hindered cyclohexene ring are not suitable candidates for the tandem metathesis sequence.

\section{Experimental General}

Reactions involving organometallic species were carried out under nitrogen by using oven-dried glassware and syringes. THF and $\mathrm{Et}_{2} \mathrm{O}$ were distilled from sodium/benzophenone under nitrogen immediately prior to use. Dichloromethane was distilled over $\mathrm{P}_{2} \mathrm{O}_{5}$. TLC was performed by using $(10 \times 5 \mathrm{~cm})$ glass plates coated with Acme's silica gel GF254 (containing 13\% calcium sulfate as a binder). Flash-column chromatography was performed by using Aceme silica gel (100-200 mesh). Solvents were concentrated at reduced pressure on a Büchi R-114 rotary evaporator. ${ }^{1} \mathrm{H}$ NMR (400 MHz) and ${ }^{13} \mathrm{C}$ NMR $(75.1 \mathrm{MHz})$ spectra were recorded at $\mathrm{rt}$ on a Bruker AX 400 with TMS ( $\delta=0.0 \mathrm{ppm},{ }^{1} \mathrm{H}$ NMR spectra) and $\mathrm{CDCl}_{3}\left(\delta=77.0 \mathrm{ppm},{ }^{13} \mathrm{C}\right.$ NMR spectra $)$ as internal standards. IR spectra were recorded on a Nicolet Impact-400 FTIR spectrometer. HRMS were determined on a Micromass Q-ToF spectrometer.

\section{Materials}

Grubbs' $1^{\text {st }}$ and $2^{\text {nd }}$ generation and Grubbs-Hoveyda catalysts were purchased from Aldrich, Milwaukee (USA). Compounds $18,19,20$, and 21 were prepared by procedures similar to those described in [28] for analogous compounds.

\section{Preparation of 2,5-diallyl-1,4-benzoquinone (18)}

To a solution of 2,5-diallyl-1,4-hydroquinone (17, $1.8 \mathrm{~g}$, $9.45 \mathrm{mmol})$ in acetone $(50 \mathrm{~mL})$ was added $\mathrm{MnO}_{2}$ in excess ( 8 equiv) at rt. After completion of the reaction (TLC monitoring, $15 \mathrm{~h}$ ), the reaction mixture was filtered off by using a pad of celite. The filtrate was evaporated to dryness and the residue was purified by distillation under reduced pressure at $106-107{ }^{\circ} \mathrm{C}(1 \mathrm{mmHg})$ to give $\mathbf{1 8}$ as a dark yellow oil (1.2 g, 67\%). Bp: $106-107{ }^{\circ} \mathrm{C}$ at $1.0 \mathrm{mmHg}$ (Lit. Bp: $105^{\circ} \mathrm{C}$ at $1.0 \mathrm{mmHg})[16]$.

\section{Preparation of 2,5-diallyltricyclo[6.2.1.0 2,7$]$ undeca- 4,9-diene-3,6-dione (19)}

To a cooled solution (at $0{ }^{\circ} \mathrm{C}$ ) of 2,5-diallyl-1,4-benzoquinone $(\mathbf{1 8}, 1.17 \mathrm{~g}, 6.21 \mathrm{mmol})$ in methanol $(25 \mathrm{~mL})$ was added freshly prepared 1,3-cyclopentadiene $(0.48 \mathrm{~mL}, 6.24 \mathrm{mmol})$ in a dropwise manner. After completion of the reaction (TLC monitoring, $11 \mathrm{~h}$ ), the solvent was evaporated under reduced pressure, and the residue was purified by silica-gel column chromatography ( $3 \%$ ethyl acetate/petroleum ether) to give 19 (1.13 g, $71.5 \%$ ) as a thick yellow liquid. IR (Neat) $v_{\max }$ : 1337, 1666, $2991 \mathrm{~cm}^{-1}$; ${ }^{1} \mathrm{H}$ NMR $\left(400 \mathrm{MHz}, \mathrm{CDCl}_{3}\right) \delta 1.4(\mathrm{~d}, J=8.8 \mathrm{~Hz}$, $1 \mathrm{H}), 1.6(\mathrm{~d}, J=9.2 \mathrm{~Hz}, 1 \mathrm{H}), 2.16\left(\mathrm{dd}, J_{1}=8.8 \mathrm{~Hz}, J_{2}=8.2 \mathrm{~Hz}\right.$, $1 \mathrm{H}), 2.82\left(\mathrm{dd}, J_{1}=J_{2}=6.7 \mathrm{~Hz}, 1 \mathrm{H}\right), 2.90-3.10(\mathrm{~m}, 4 \mathrm{H}), 3.3(\mathrm{~s}$, $1 \mathrm{H}), 4.42-5.12(\mathrm{~m}, 4 \mathrm{H}), 5.92-5.94(\mathrm{~m}, 1 \mathrm{H}), 5.63-5.73(\mathrm{~m}, 1 \mathrm{H})$, $5.93\left(\mathrm{dd}, J_{1}=2.0 \mathrm{~Hz}, J_{2}=3.0 \mathrm{~Hz}, 1 \mathrm{H}\right), 6.05\left(\mathrm{dd}, J_{1}=2.0 \mathrm{~Hz}\right.$, 
$\left.J_{2}=3.0 \mathrm{~Hz}, 1 \mathrm{H}\right), 6.3(\mathrm{~s}, 1 \mathrm{H}) \mathrm{ppm} ;{ }^{13} \mathrm{C} \mathrm{NMR}(100.6 \mathrm{MHz}$, $\left.\mathrm{CDCl}_{3}\right) \delta 32.8,44.9,46.4,49.3,53.1,54.4,57.4,118.2,132.8$, 133.1, 134.9, 137.4, 139.55, 139.58, 152.3, 198.8, 202.0 ppm; HRMS (Q-ToF ES+) $\mathrm{m} / \mathrm{z}$ : calcd for $\mathrm{C}_{17} \mathrm{H}_{18} \mathrm{O}_{2} \mathrm{~K}, 293.0944$; found, $293.1086[\mathrm{M}+\mathrm{K}]^{+}$.

\section{Preparation of 1,9-diallylpenta-}

\section{cyclo[5.4.0.0 2,6 $.0^{3,10} \cdot 0^{5,9}$ ] undeca-8,11-dione (20)}

Tricyclic dione 19 (125 mg, $0.49 \mathrm{mmol}$ ) was dissolved in dry ethyl acetate $(500 \mathrm{~mL})$ and irradiated in a Pyrex immersion well by a $125 \mathrm{~W}$ lamp (homemade) for $1.5 \mathrm{~h}$ under nitrogen at $\mathrm{rt}$. After completion of the reaction (TLC monitoring), the solvent was evaporated under reduced pressure and the residue was purified by silica gel column chromatography ( $5 \%$ ethyl acetate/ petroleum ether) to give $\mathbf{2 0}(80 \mathrm{mg}, 80 \%)$ as a thick pale yellow liquid. IR (KBr) $v_{\max }: 3073,2974,1752,1636,924 \mathrm{~cm}^{-1}$; ${ }^{1} \mathrm{H}$ NMR (400 MHz, $\left.\mathrm{CDCl}_{3}\right) \delta 1.82(\mathrm{~d}, J=11.4 \mathrm{~Hz}, 1 \mathrm{H}), 2.12$ $(\mathrm{d}, J=11.4 \mathrm{~Hz}, 1 \mathrm{H}) 2.15-2.4(\mathrm{~m}, 6 \mathrm{H}), 2.55\left(\mathrm{dd}, J_{1}=J_{2}=1.0\right.$ $\mathrm{Hz}, 1 \mathrm{H}), 2.7\left(\mathrm{dd}, J_{1}=J_{2}=1.0 \mathrm{~Hz}, 1 \mathrm{H}\right), 2.8-3.1(\mathrm{~m}, 2 \mathrm{H})$, 5.0-5.2 (m, 4H), 5.6-5.9 (m, 2H) ppm; ${ }^{13} \mathrm{C}$ NMR (100.6 MHz, $\left.\mathrm{CDCl}_{3}\right) \delta 33.7,35.3,35.6,39.7,42.9,44.0,47.3,47.8,51.5$, $60.2,61.6,118.5,118.7,132.9,133.7,212.5,213.6 \mathrm{ppm}$; HRMS (Q-ToF ES+) $m / z$ : calcd for $\mathrm{C}_{17} \mathrm{H}_{19} \mathrm{O}_{2} \mathrm{Na}, 277.1204$; found, $277.1210[\mathrm{M}+\mathrm{Na}]^{+}$.

\section{Preparation of pentacyclic tetraallyldiol $\mathbf{2 1}$}

To a freshly prepared solution of allylmagnesium bromide in ether was added an ethereal solution of pentacyclic dione $\mathbf{2 0}$ (300 $\mathrm{mg}, 1.18 \mathrm{mmol}$ ) in a dropwise manner over a period of 10-15 min at $\mathrm{rt}$ under nitrogen. After completion of the reaction (TLC monitoring, $10 \mathrm{~h}$ ), the reaction was quenched with a saturated aqueous $\mathrm{NH}_{4} \mathrm{Cl}$ solution at $0{ }^{\circ} \mathrm{C}$. Then, the aqueous layer was extracted by ethyl acetate $(3 \times 25 \mathrm{~mL})$. The combined organic layer was washed with brine, and dried over anhydrous $\mathrm{Na}_{2} \mathrm{SO}_{4}$. After the removal of the solvent under reduced pressure, the residue was purified by silica gel column chromatography (4\% ethyl acetate/petroleum ether) to give 21 (280 mg, $70 \%$ ) as a white solid. Mp: $158-160{ }^{\circ} \mathrm{C}$; IR (KBr) $v_{\max }: 3309$, 3055, 2977, 1265, 743, $705 \mathrm{~cm}^{-1}$; ${ }^{1} \mathrm{H}$ NMR (400 MHz, $\left.\mathrm{CDCl}_{3}\right)$ $\delta 1.3\left(1 / 2 \mathrm{ABq}, J_{1}=10.9 \mathrm{~Hz}, J_{2}=11.0 \mathrm{~Hz}, 2 \mathrm{H}\right), 1.96-2.19(\mathrm{~m}$, $6 \mathrm{H}), 2.23-2.46(\mathrm{~m}, 8 \mathrm{H}) 5.08-5.10(\mathrm{~m}, 8 \mathrm{H}), 5.9-6.1(\mathrm{~m}, 4 \mathrm{H})$ ppm; ${ }^{13} \mathrm{C}$ NMR $\left(100.6 \mathrm{MHz}, \mathrm{CDCl}_{3}\right) \delta 33.1,35.2,36.6,38.1$, 41.1, 42.2, 43.1, 44.2, 45.2, 49.0, 49.5, 55.5, 55.7, 78.9, 80.5, $116.71,116.72,117.4,118.3,134.1,134.7,136.1,136.3$ ppm; HRMS (Q-ToF ES+) $m / z$ : calcd for $\mathrm{C}_{23} \mathrm{H}_{30} \mathrm{O}_{2} \mathrm{Na}, 361.2144$; found, $361.2146[\mathrm{M}+\mathrm{Na}]^{+}$.

\section{Preparation of heptacyclic diol 22}

To a solution of 21 ( $25 \mathrm{mg}, 0.074 \mathrm{mmol}$ ) was added Grubbs' $2^{\text {nd }}$ generation catalyst ( $4 \mathrm{mg}, 6 \mathrm{~mol} \%$ ) under argon at rt. After completion of the reaction (TLC monitoring, $8 \mathrm{~h}$ ), the solvent was evaporated and the resulting residue was purified by silica gel column chromatography (25\% ethyl acetate/petroleum ether) to give 22 (15 mg, 72\%) as a white crystalline solid. Mp: 206-207 ${ }^{\circ} \mathrm{C}$; IR (KBr) $v_{\max }: 3691,3054,2987,2305,1422$, $1266 \mathrm{~cm}^{-1} ;{ }^{1} \mathrm{H}$ NMR $\left(400 \mathrm{MHz}, \mathrm{CDCl}_{3}\right) \delta 1.38\left(1 / 2 \mathrm{AB} \mathrm{q}, J_{1}=\right.$ $\left.J_{2}=11.0 \mathrm{~Hz}, 2 \mathrm{H}\right), 1.79(\mathrm{q}, J=1.8 \mathrm{~Hz}, 1 \mathrm{H}), 1.99-2.56(\mathrm{~m}$, $13 \mathrm{H}), 5.54-5.72(\mathrm{~m}, 4 \mathrm{H}) \mathrm{ppm} ;{ }^{13} \mathrm{C} \mathrm{NMR}\left(100.6 \mathrm{MHz}, \mathrm{CDCl}_{3}\right)$ $\delta 31.0,31.4,32.4,36.2,37.1,37.7,44.2,44.5,45.1,47.3,49.6$, 51.4, 58.6, 74.7, 75.0, 123.1, 124.1, 124.4, 126.3 ppm; HRMS (Q-ToF ES+) $m / z$ : calcd for $\mathrm{C}_{19} \mathrm{H}_{22} \mathrm{O}_{2} \mathrm{Na}, 305.1517$; found, $305.1523[\mathrm{M}+\mathrm{Na}]^{+}$.

\section{Preparation of hexacyclic diallyldiol 24}

To a freshly prepared solution of allylmagnesium bromide (6 equiv) in ether was added the ethereal solution of hexacyclic dione 23 (200 mg, $0.88 \mathrm{mmol}$ ) in a dropwise manner over a period of 10-15 min under nitrogen at rt. After completion of the reaction (TLC monitoring, $8 \mathrm{~h}$ ), the reaction mixture was quenched with saturated aqueous $\mathrm{NH}_{4} \mathrm{Cl}$ solution at $0{ }^{\circ} \mathrm{C}$. Then, the aqueous layer was extracted by ethyl acetate $(3 \times 25 \mathrm{~mL})$. The combined organic layer was washed with brine and dried over anhydrous $\mathrm{Na}_{2} \mathrm{SO}_{4}$. After removal of the solvent under reduced pressure, the resulting residue was purified by silica-gel column chromatography (4\% ethyl acetate/petroleum ether) to give 24 (232 $\mathrm{mg}, 82 \%)$ as a white crystalline solid. Mp: 177-178 ${ }^{\circ} \mathrm{C}$; IR (KBr) $v_{\max }: 3339,3054,2985,1422,1265$ $\mathrm{cm}^{-1} ;{ }^{1} \mathrm{H} \mathrm{NMR}\left(400 \mathrm{MHz}, \mathrm{CDCl}_{3}\right) \delta 1.38\left(1 / 2 \mathrm{ABq}, J_{1}=J_{2}=\right.$ $10.3 \mathrm{~Hz}, 2 \mathrm{H}), 1.9-2.0(\mathrm{~m}, 6 \mathrm{H}), 2.13-2.25$ (m, 6H), 2.32 (d, $J=$ $1.6 \mathrm{~Hz}, 2 \mathrm{H}), 5.10-5.17(\mathrm{~m}, 4 \mathrm{H}), 5.91-6.02(\mathrm{~m}, 4 \mathrm{H}) \mathrm{ppm}$; ${ }^{13} \mathrm{C}$ NMR $\left(100.6 \mathrm{MHz}, \mathrm{CDCl}_{3}\right) \delta 26.2,34.7,42.1,43.4,43.7$, 48.8, 51.4, 78.3, 117.9, 128.2, 134.0 ppm; HRMS (Q-ToF ES+) $\mathrm{m} / \mathrm{z}$ : calcd for $\mathrm{C}_{20} \mathrm{H}_{27} \mathrm{O}_{2}, 311.2011$; found, $311.2012[\mathrm{M}+\mathrm{H}]^{+}$.

\section{Preparation of hexacyclic diallyldiol $\mathbf{2 6}$}

To a freshly prepared solution of allylmagnesium bromide (6 equiv) in ether was added the ethereal solution of hexacyclic dione 25 (250 mg, $1.12 \mathrm{mmol}$ ) in a dropwise manner over a period of 10-15 min under nitrogen at rt. After completion of the reaction (TLC monitoring, $8 \mathrm{~h}$ ), the reaction mixture was quenched with saturated aqueous $\mathrm{NH}_{4} \mathrm{Cl}$ solution at $0{ }^{\circ} \mathrm{C}$. Then, the aqueous layer was extracted with ethyl acetate $(3 \times 25 \mathrm{~mL})$. The combined organic layer was washed with brine and collected over anhydrous $\mathrm{Na}_{2} \mathrm{SO}_{4}$. After removal of the solvent under reduced pressure, the resulting residue was purified by silica-gel column chromatography (4\% ethyl acetate/petroleum ether) to give $\mathbf{2 6}(292 \mathrm{mg}, 85 \%)$ as a white crystalline solid. Mp: $191-192{ }^{\circ} \mathrm{C}$; IR (KBr) $v_{\max }$ : 3339, 3055, 2961, 1439, 1265 $\mathrm{cm}^{-1} ;{ }^{1} \mathrm{H}$ NMR $\left(400 \mathrm{MHz}, \mathrm{CDCl}_{3}\right) \delta 0.90(\mathrm{~d}, J=10.8 \mathrm{~Hz}, 1 \mathrm{H})$, $1.40(\mathrm{~d}, J=10.8 \mathrm{~Hz}, 1 \mathrm{H}), 2.02-2.07(\mathrm{~m}, 2 \mathrm{H}), 2.26(\mathrm{~s}, 2 \mathrm{H})$, 2.34-2.39 (m, 4H), $2.73(\mathrm{~s}, 2 \mathrm{H}), 4.84$ (brs, 2H), 5.10-5.15 (m, $4 \mathrm{H}), 5.56\left(\mathrm{dd}, J_{1}=10.7 \mathrm{~Hz}, J_{2}=2.7 \mathrm{~Hz}, 2 \mathrm{H}\right), 5.89-6.01(\mathrm{~m}$, 
4H) ppm; $\left.{ }^{13} \mathrm{C} \mathrm{NMR} \mathrm{(100.6} \mathrm{MHz,} \mathrm{CDCl}_{3}\right) \delta 31.7,42.1,44.0$, 48.6, 51.3, 54.1, 78.8, 118.2, 124.3, 124.4, 133.7 ppm; HRMS (Q-ToF ES+) $m / z$ : calcd for $\mathrm{C}_{21} \mathrm{H}_{25} \mathrm{O}_{2}, 309.1855$; found, $309.1862[\mathrm{M}+\mathrm{H}]^{+}$.

\section{Supporting Information}

\section{Supporting Information File 1}

Copies of ${ }^{1} \mathrm{H},{ }^{13} \mathrm{C}$ NMR and HRMS spectra for all new compounds.

[http://www.beilstein-journals.org/bjoc/content/ supplementary/1860-5397-10-280-S1.pdf]

\section{Acknowledgements}

We would like to thank the DST (New Delhi) for financial support. MKD thanks CSIR (New Delhi) for awarding a research fellowship. SK thanks DST for the award of a J. C. Bose Fellowship.

\section{References}

1. Marchand, A. P. Aldrichimica Acta 1995, 28, 95.

2. Marchand, A. P. In Advances in Theoretically Interesting Molecules; Thummel, R. P., Ed.; JAI: Greenwich, CT, 1989; Vol. 1, pp 357 ff.

3. Mehta, G.; Srikrishna, A. Chem. Rev. 1997, 97, 671. doi:10.1021/cr9403650

4. Fessner, W. D.; Sedelmeier, G.; Spurr, P. R.; Rihs, G.; Prinzbach, H. J. Am. Chem. Soc. 1987, 109, 4626. doi:10.1021/ja00249a029

5. Olah, G. Cage Hydrocarbons; John-Wiley and Sons: New York, 1990.

6. Osawa, E.; Yonemitsu, O. Carbocyclic Caged Compounds; VCH: New York, 1992.

7. Hargittai, I.; Hargittai, M. Symmetry through the Eyes of a Chemist; Wiley: New York, 1987.

8. Hopf, H. Classics in Hydrocarbon Chemistry; Wiley-VCH: Weinheim, 2000.

9. McGlinchey, M. J.; Hopf, H. Beilstein J. Org. Chem. 2011, 7, 222. doi:10.3762/bjoc.7.30

10. Van der Schyf, C. J.; Dekker, T. G.; Snyckers, F. O. Arch. Pharm. 1986, 319, 409. doi:10.1002/ardp.19863190506

11. Van der Schyf, C. J.; Dekker, T. G.; Snyckers, F. Q.; Squier, G. J.; Coetzee, W. A.; Van der Walt, J. J.; Fourie, T. G.; Liebenberg, W. Polycyclic compounds and pharmaceutical compositions thereof. Eur. Pat. EP0312245, April 19, 1989.

12. Oliver, D. W.; Malan, S. F. Med. Chem. Res. 2008, 17, 137. doi:10.1007/s00044-007-9044-5

13. Marchand, A. P.; Kruger, H. G.; Power, E. D.; Segal, C. Kem. Ind. 2002, 51, 51

14. Marchand, A. P.; Dave, P. R.; Rajapaksa, D.; Arney, B. E., Jr.; Flippen-Anderson, J. L.; Gilardi, R.; George, C. J. Org. Chem. 1989, 54, 1769. doi:10.1021/jo00268a056

15. Marchand, A. P.; Arney, B. E., Jr.; Dave, P. R. J. Org. Chem. 1988, 53, 443. doi:10.1021/jo00237a046

16. Govender, T.; Hariprakasha, H. K.; Kruger, H. G.; Marchand, A. P. Tetrahedron: Asymmetry 2003, 14, 1553. doi:10.1016/S0957-4166(03)00272-6
17. Marchand, A. P.; Chong, H.-S.; Ganguly, B. Tetrahedron: Asymmetry 1999, 10, 4695. doi:10.1016/S0957-4166(99)00549-2

18. Chamot, E.; Paquette, L. A. J. Org. Chem. 1978, 43, 4527. doi:10.1021/jo00417a031

19. Paquette, L. A.; Beckley, R. S. J. Am. Chem. Soc. 1975, 97, 1084. doi:10.1021/ja00838a023

20. Maier, G.; Pfriem, S.; Schäfer, U.; Matusch, R. Angew. Chem. 1978, 90, 552. doi:10.1002/ange.19780900714 Angew. Chem., Int. Ed. Engl. 1978, 14, 520. doi:10.1002/anie.197805201

21. Katz, T. J.; Acton, N. J. Am. Chem. Soc. 1973, 95, 2738 doi:10.1021/ja00789a084

22. McNichols, A. T.; Stang, P. J. Synlett 1992, 971. doi:10.1055/s-1992-21549

23. Eaton, P. E.; Cole, T. W. J. Am. Chem. Soc. 1964, 86, 962. doi:10.1021/ja01059a072

24. Mehta, G.; Padma, S. J. Am. Chem. Soc. 1987, 109, 7230. doi:10.1021/ja00257a076

25. Ternansky, R. J.; Balogh, D. W.; Paquette, L. A. J. Am. Chem. Soc. 1982, 104, 4503. doi:10.1021/ja00380a040

26. Prakash, G. K. S.; Krishnamurthy, V. V.; Herges, R.; Bau, R.; Yuan, H.; Olah, G. A.; Fessner, W.-D.; Prinzbach, H. J. Am. Chem. Soc. 1986, 108, 836. doi:10.1021/ja00264a046

27. Mehta, G.; Reddy, S. H. K. Angew. Chem. 1993, 105, 1230. doi:10.1002/ange.19931050825 Angew. Chem., Int. Ed. Engl. 1993, 32, 1160. doi:10.1002/anie.199311601

28. Kotha, S.; Dipak, M. K. Chem. - Eur. J. 2006, 12, 4446 doi:10.1002/chem.200501366

29. Fieser, L. F.; Campbell, W. P.; Fry, E. M. J. Am. Chem. Soc. 1939, 61, 2206. doi:10.1021/ja01877a068

30. Martin Castro, A. M. Chem. Rev. 2004, 104, 2939. doi:10.1021/cr020703u

31. Griesbeck, A. G. Tetrahedron Lett. 1988, 29, 3477. doi:10.1016/0040-4039(88)85194-3

32. Grubbs, R. H. Tetrahedron 2004, 60, 7117. doi:10.1016/j.tet.2004.05.124

33. Deiters, A.; Martin, S. F. Chem. Rev. 2004, 104, 2199 doi:10.1021/cr0200872

34. McReynolds, M. D.; Dougherty, J. M.; Hanson, P. R. Chem. Rev. 2004, 104, 2239. doi:10.1021/cr020109k

35. Schrock, R. R.; Hoveyda, A. H. Angew. Chem. 2003, 115, 4740. doi:10.1002/ange. 200300576 Angew. Chem., Int. Ed. 2003, 42, 4592. doi:10.1002/anie.200300576 36. Kotha, S.; Sreenivasachary, N. Indian J. Chem., Sect. B 2001, 40, 763 37. Kotha, S.; Lahiri, K. Synlett 2007, 2767. doi:10.1055/s-2007-990954

38. Valmiki Ramayana; Geeta Press: Gorakhpur, Uttar Pradesh, India; Sloka 6-7, p. 1425.

39. Chitra Ramayana by Ramachandra Madhwa Mahishi, Illustrated by Balasaheb Pandit Pant Pratinidhi, 1916.

40. Nickon, A.; Silversmith, E. F. Organic Chemistry. The Name Game Modern Coined Terms and Their Origins; Pergamon Press, 1987.

41. Since the shape of molecule 22 resembles the ancient flying machine "Pushpak Viman" we coined the name 'pushpakenediol' for this dihydroxy caged system.

42. Holub, N.; Blechert, S. Chem. - Asian J. 2007, 2, 1064. doi:10.1002/asia.200700072

43. Mehta, G.; Uma, R. Acc. Chem. Res. 2000, 33, 278. doi:10.1021/ar990123s 


\section{License and Terms}

This is an Open Access article under the terms of the Creative Commons Attribution License

(http://creativecommons.org/licenses/by/2.0), which permits unrestricted use, distribution, and reproduction in any medium, provided the original work is properly cited.

The license is subject to the Beilstein Journal of Organic Chemistry terms and conditions:

(http://www.beilstein-journals.org/bjoc)

The definitive version of this article is the electronic one which can be found at:

doi:10.3762/bjoc. 10.280 